\title{
BIOCHAR DAN KOMPOS UNTUK PENINGKATAN SIFAT FISIKA TANAH DAN EFISIENSI PENGGUNAAN AIR
}

\author{
Indah Nurul Safitri 1, Tricandra Setiawati 2, Cahyoadi Bowo*3 \\ 1,2,3Program Studi Agroteknologi, Fakultas Pertanian Universitas Jember \\ *Corresponding Author: cahyoadi.bowo.faperta@unej.ac.id \\ Manuscript received: 14-03-2018 Revision accepted: 02-05-2018
}

\begin{abstract}
Abstrak
Biochar merupakan mineral amorf digunakan sebagai bahan pembenah tanah. Biochar dikombinasikan dengan kompos untuk memperbaiki sifat fisika tanah dengan indikator tanaman Jagung Manis. Penelitian dilaksanakan pada bulan Mei-Agustus 2017 di Agrotekhnopark Universitas Jember. Rancangan percobaan yang digunakan adalah Rancangan Acak Kelompok (RAK) Faktorial 2x5 dengan tiga ulangan. Faktor pertama adalah kompos terdiri dari kontrol (K0) dan kompos 10 ton/ha (K1) dan faktor kedua adalah biochar terdiri dari kontrol (B0), biochar batang jagung 20 ton/ha (B1) dan 40 ton/ha (B2), biochar jerami padi 20 ton/ha (B3) dan 40 ton/ha (B4). Hasil penelitian menunjukkan pemberian kompos 10 ton/ha dan biochar batang jagung 40 ton/ha mampu menurunkan BV (26,5\%), meningkatkan porositas $(9,2 \%)$, meningkatkan pori air tersedia $(61,9 \%)$. Pemberian biochar batang jagung 40 ton/ha meningkatkan berat basah $(20,6 \%)$ dan berat kering tanaman $(30,1 \%)$. Kombinasi perlakuan kompos (10 ton/ha) dan biochar jerami (40 ton/ha) mampu menurunkan kebutuhan air tanaman sebesar $34,4 \%$. Pemberian biochar mampu mengefisiensi penggunaan air tanaman tertinggi sebesar $0,77 \mathrm{~g} / \mathrm{mm}$ dibandingkan dengan kontrol sebesar $0,51 \mathrm{~g} / \mathrm{mm}$ setiap tanaman.
\end{abstract}

Kata kunci: Alfisol, biochar, kompos, efisiensi air, jagung manis

\section{Abstract}

Biochar is amorphous mineral and widely used as soil ameliorant. In this study biochar in combination with compost was applied to improve soil physical properties and water use efficiency (WUE) of sweet corn. The field experiment was undertaken from May to August 2017 at Agrotechnopark University of Jember. Randomized Completely Block Design (RCBD) Factorial 2x5 with three replications was used as experimental design. The first factor was compost consisted of 0 ton/ha (K0) and 10 ton/ha (K1. The second factor was biochar consisted of 0 ton/ha (B0), 20 ton/ha (B1), 40 ton/ha (B2) corn stalk biochar, and 20 ton/ha (B3), 40 ton/ha (B4) rice straw biochar. Our results showed combination of 10 tons/ha of compost and 40 ton/ha corn stalk biochar decreased BD (26,5\%), increased porosity $(9,2 \%)$ and available water pore $(61,9 \%)$, but decreased the plant water requirement $(34.4 \%)$. Application of biochar significantly improved water use efficiency (WUE) of sweet corn by $0.77 \mathrm{~g} / \mathrm{mm}$ in compare to without biochar by $0.51 \mathrm{~g} / \mathrm{mm}$.

Keywords: Alfisol, biochar, compost, water use efficiency, sweet corn 


\section{PENDAHULUAN}

Alfisol merupakan salah satu tanah yang banyak mendominasi tanah di Indonesia. Munir (1996) menyatakan bahwa luas tanah Alfisol di Indonesia mencapai 12.749 .000 hektar menyebar di Pulau Jawa, Sumatera, Kalimantan, Sulawesi, Papua, Bali, Nusa Tenggara Barat dan Nusa Tenggara Timur. Karakteristik utama Alfisol adalah banyak mengalami penimbunan klei (clay) dari horison-horison di atasnya sehingga memiliki kepadatan tanah tinggi yang sulit ditembus perakaran tanaman, rendahnya kandungan bahan organik, pori aerasi dan kapasitas memegang air (Wijanarko, 2007; Pathak et al. 2013).

Upaya perbaikan pada tanah Alfisol selama ini dilakukan dengan pemberian bahan organik kompos. Kompos mampu memperbaiki sifat-sifat tanah namun mudah terdekomposisi oleh mikroba tanah sehingga membutuhkan dosis yang cukup tinggi dan dalam jumlah yang cukup besar (Nurida, 2014). Berdasar hal tersebut, dibutuhkan bahan organik yang sulit terdekomposisi di dalam tanah sehingga mampu bertahan lama di dalam tanah dan tidak perlu diberikan setiap tahun.

Salah satu bahan yang sulit terdekomposisi dalam tanah yaitu biochar. Menurut Hartatik et al. (2015), biochar merupakan padatan berupa arang yang kaya karbon (C) hasil konversi dari biomas melalui proses pembakaran tidak sempurna dengan minimum oksigen (pirolisis). Biochar memiliki sifat lebih stabil dalam tanah dan sukar teroksidasi (Mawardiana et al., 2013). Biochar sebagai pembenah bagi tanah mampu memperbaiki sifat tanah seperti meningkatkan stabilitas agregat tanah, meningkatkan permeabilitas, memperbaiki aerasi tanah, meningkatkan kandungan c-organik tanah, mampu meretensi hara dan air agar tersedia untuk tanaman (Widowati et al., 2013).

Aplikasi biochar dan kompos dilakukan untuk meningkatkan kesuburan dan ketersediaan air tanah untuk memenuhi kebutuhan tanaman. Pada penelitian ini digunakan tanaman jagung manis (Zea mays saccharata STURT L.) sebagai indikator tanaman. Jagung manis merupakan salah satu tanaman yang memerlukan banyak air selama masa pertumbuhannya. Aplikasi biochar dan kompos pada tanah merupakan langkah untuk meningkatkan ketersediaan air pada tanah sehingga dapat meningkatkan produktivitas jagung manis yang saat ini banyak dikembangkan oleh masyarakat.

Tujuan penelitian adalah untuk mengkaji pengaruh kombinasi biochar dan kompos terhadap efisiensi penggunaan air tanaman jagung manis. Aplikasi biochar diharapkan lebih efektif dalam memperbaiki sifat fisika tanah dan lebih efisien dalam penggunaan air untuk produksi jagung manis.

\section{METODE PENELITIAN}

Penelitian dilaksanakan di lahan Agrotekhnopark Universitas Jember (8,1630 LS; 113,7170 BT) ketinggian $122 \mathrm{~m}$ dpl. Contoh tanah Alfisol diambil di Sucopangepok, Kabupaten Jember, kompos, batang jagung, jerami padi, kayu bakar, spritus, karung, benih jagung manis varietas Pertiwi, pupuk NPK (12:11:16), pupuk urea, pupuk SP-36, aquadest dan $\mathrm{H}_{2} \mathrm{O}_{2}$. Alat yang digunakan antara lain tong minyak, ayakan, timba $(\mathrm{d}=28 \mathrm{~cm}, \mathrm{t}=27 \mathrm{~cm})$, timbangan analitik, 
ring sampel, oven, $\mathrm{pH}$ meter, $\mathrm{pF}$ meter, piknometer, gelas ukur, penggaris, gembor dan alat ukur stasiun iklim otomatis.

Rancangan percobaan yang digunakan adalah rancangan acak kelompok (RAK) Faktorial 2x5 dengan tiga ulangan. Faktor pertama kompos terdiri dari kontrol (K0) dan kompos 10 ton/ha (K1) dan faktor kedua adalah biochar yang terdiri dari kontrol (B0), biochar batang jagung 20 ton/ha (B1) dan 40 ton/ha (B2), biochar jerami padi 20 ton/ha (B3) dan 40 ton/ha (B4). Selanjutnya dilakukan uji lanjut menggunakan Uji Duncan Multiple Range Test (DMRT) pada data yang diperoleh untuk mengetahui pengaruh setiap perlakuan terhadap berbagai variabel yang diamati.

\section{Tahapan Pelaksanaan Penelitian}

\section{Pembuatan Biochar}

Menyiapkan alat (tong minyak dan ayakan) dan bahan (jerami, batang jagung, kayu bakar dan spiritus) dan mengeringkan bahan terlebih dahulu. Jerami dan jagung dipotong menjadi lebih kecil sekitar 10-15 cm kemudian dimasukkan dalam tong sampai $3 / 4$ penuh. Bagian atas tong diisi kayu bakar dan kertas. Kayu yang terdapat dibagian atas dibakar, kemudian tong ditutup rapat agar tidak ada oksigen masuk. Proses pirolisis dilakukan selama 2-3 jam. Setelah 2-3 jam dan tidak keluar asap, arang hasil pembakaran dituang ke tanah dan langsung disiram, kemudian arang yang dihasilkan diayak dengan ayakan 0,5 cm. Arang yang dihasilkan dimasukkan dalam karung dan disimpan sebelum digunakan.

\section{Persiapan Media dan Penanaman}

Tanah Alfisol yang diambil di Sucopangepok dihancurkan kemudian dikeringanginkan dan diayak dengan ayakan $2 \mathrm{~mm}$. Tanah yang digunakan sebanyak $12 \mathrm{~kg} /$ pot (3/4 volume pot), kemudian diberikan perlakuan dan diinkubasikan selama 1,5 bulan sebelum penanaman.

Penanaman dilakukan dengan menanam benih jagung manis pada kedalaman lubang tanam $\pm 5 \mathrm{~cm}$. Benih jagung manis ditanam 3-5 benih perlubang kemudian ditutup dengan tanah agar benih dapat cepat berkecambah.

\section{Pemupukan dan Pemeliharaan}

Pupuk dasar diberikan pada saat awal tanam NPK (12:11:16) dan SP36. Urea sebagai pupuk susulan diberikan pada 18HST dan 50HST. Pupuk yang diberikan pada tanaman jagung manis Urea $200 \mathrm{~kg} / \mathrm{ha}$ (3 g/tanaman), SP36 sebesar $100 \mathrm{~kg} / \mathrm{ha}(2 \mathrm{~g} /$ tanaman $)$ dan NPK sebesar $100 \mathrm{~kg} / \mathrm{ha}(10 \mathrm{~g} /$ tanaman). Pupuk yang diaplikasikan hanya 70\% dari rekomendasi pemupukan. Pemeliharaan terdiri dari penyulaman, penyiangan dengan mencabut gulma, dan penjarangan dengan mencabut tanaman yang kurang baik sehingga tersisa tanaman terbaik untuk dipelihara sampai panen. Pengendalian hama dan penyakit menggunakan bakterisida Dithane karena tanaman jagung manis pada saat memasuki fase generatif terkena penyakit hawar daun. 


\section{Pengumpulan dan Pengolahan Data}

Variabel tanah yang diamati adalah tekstur tanah menggunakan metode pipet. Berat volume tanah ditetapkan dengan metode ring sample. Penetapan berat jenis partikel (BJP) melalui metode piknometer. Porositas menggunakan metode perbandingan berat volume dan berat jenis partikel tanah. Distribusi pori tanah diukur dengan pengukuran $\mathrm{pF}$ menggunakan panci tekan. Variabel tanaman terdiri dari berat basah dan berat kering tanaman.

Variabel pengamatan di lapangan meliputi data iklim terdiri dari curah hujan menggunakan ombrometer, temperatur menggunakan termometer, kelembapan udara menggunakan hygrometer, kecepatan angin menggunakan anemomter, radiasi matahari menggunakan sunshine recorder, evaporasi dengan panci evaporasi dan rangkaian Automatic Weather Station (AWS). Data iklim digunakan untuk menghitung Evapotranspirasi referens $\left(\mathrm{ET}_{0}\right)$. $\mathrm{ET}_{0}$ dihitung dengan metode FAO-Penman-Monteith (Allen et al., 2006) dengan persamaan:

$$
E T_{0}=\frac{0,408 \Delta\left(R_{n}-G\right)+\gamma \frac{900}{T+273} U_{2}\left(e_{s}-e_{a}\right)}{\Delta+\gamma\left(1+0,34 U_{2}\right)}
$$

Kebutuhan air tanaman dihitung sebagai jumlah evaporasi dan transpirasi atau proses evapotranspirasi (Jangpromma et al., 2012). Besarnya ETc dinyatakan dengan:

$$
E T_{c}=K_{c} \cdot E T_{0}
$$

dengan ETc- Evapotranspirasi tanaman (mm); Kc- Koefisien tanaman (-); ET0-Evapotranspirasi referens $(\mathrm{mm})$. Efisiensi penggunaan air untuk setiap perlakuan dihitung menggunakan rumus yang digunakan oleh Anyia dan Herzog (2004) dan Singh et al. (2012):

$$
E P A=\frac{B K}{E T_{C}}
$$

dengan EPA (Efisiensi Penggunaan Air (g/mm)); BK (Berat kering tanaman (g)); ETc (Kebutuhan air tanaman (mm)).

\section{Meteorologi Lokasi Penelitian}

Kondisi iklim selama penelitian mengalami perbedaan setiap dekade (10 hari). Curah hujan tertinggi terjadi pada dekade 15 (10 hari terakhir Mei) yaitu sebesar 77,7 mm. Diikuti dengan evapotranspirasi dan kecepatan angin tertinggi pada dekade 20 (11-20 hari Juli) secara berurutan sebesar $45,9 \mathrm{~mm} /$ dekade atau $4,6 \mathrm{~mm} /$ hari dan $0,85 \mathrm{~km} / \mathrm{jam}$. 


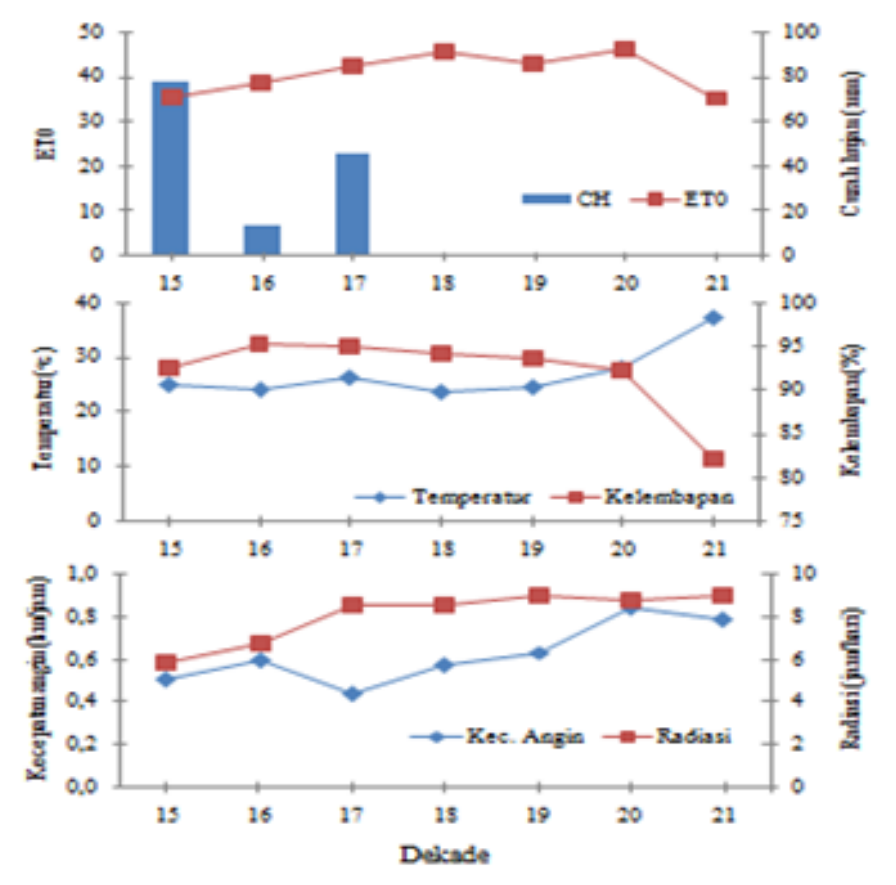

Gambar 1. Klimatologi Lokasi Penelitian

Temperatur rata-rata dan radiasi tertinggi terjadi pada dekade 21 (21-30 Juli) secara berurutan sebesar $370^{\circ} \mathrm{C}$ dan 9 jam/hari dengan kelembapan udara tertinggi terjadi pada dekade 16 (1-10 Juni) sebesar 96\%. Data iklim sangat penting karena mempengaruhi pertumbuhan dan produktivitas tanaman (Heksaputra et al., 2013).

Curah hujan yang digunakan tanaman adalah curah hujan efektif. Curah hujan efektif adalah bagian dari keseluruhan curah hujan yang secara efektif tersedia untuk kebutuhan air bagi tanaman (Dwiratna et al., 2013). Curah hujan efektif diperoleh dengan melakukan perhitungan menggunakan metode USDA dengan aplikasi software Cropwat for windows 8. Curah hujan efektif selama penelitian yang digunakan tanaman antara dekade 15-17 secara berurutan yaitu $48,7 \mathrm{~mm}, 13,1 \mathrm{~mm}$ dan $36,1 \mathrm{~mm}$.

\section{HASIL DAN PEMBAHASAN}

Tanah penelitian menunjukkan nilai $\mathrm{pH}$ tanah sebesar 5,9, tergolong agak masam dengan kadar air tanah 5,3\% karena merupakan tanah tegalan yang rentan mengalami pencucian. Menurut Suriadikarta et al. (2002) lahan tegal umumnya memiliki $\mathrm{pH}$ yang rendah yang disebabkan rendahnya kandungan bahan organik. Hal ini sesuai dengan analisis C-organik pada tanah alfisol hanya sebesar 1,21\% (rendah).

Tabel 1. Karakteristik Tanah dan Biochar

\begin{tabular}{lllll}
\hline Indikator & Tanah & Biochar Jagung & Biochar Jerami Padi & Kompos \\
\hline $\mathrm{pH} \mathrm{H} \mathrm{H}_{2} \mathrm{O}(1: 2,5)$ & 5,71 & 10,44 & 10,49 & 8,03 \\
C-Organik & 1,21 & $43,86 \%$ & $25,70 \%$ & $12,30 \%$ \\
Kadar Air & 5,3 & $4,15 \%$ & $4,61 \%$ & $8,16 \%$ \\
Tekstur Tanah & Pasir (21,4\%) & & \\
& Debu (29,8\%) & Kelas Tekstur Klei & & \\
& Klei (48,8\%) & & & \\
\hline
\end{tabular}


Tekstur tanah yang digunakan merupakan clay dengan perbandingan fraksi lempung $(48,8 \%)$, fraksi pasir $(21,4 \%)$ dan debu $(29,8 \%)$. Hal ini sesuai dengan karakteristik tanah alfisol yang merupakan tanah banyak mengandung liat sebagai akibat penimbunan dari horison-horison diatasnya sehingga memiliki kepadatan tanah yang tinggi sulit ditembus perakaran tanaman, kandungan bahan organik rendah serta memiliki pori aerasi tanah yang rendah (Wijanarko, 2007).

Kadar air pada biochar batang jagung sebesar 4,15\% lebih rendah dibandingkan dengan biochar jerami padi yang memiliki kadar air sebesar 4,61\%. C-organik biochar batang jagung sebesar 43,86\% lebih tinggi daripada C-organik biochar jerami yang hanya sebesar 25,70\%. Nilai $\mathrm{pH}$ biochar jagung dan jerami tidak jauh berbeda yaitu 10,44 dan 10,49. Maftu'ah et al. (2015) menyatakan bahwa karakteristik biochar tergantung pada bahan yang digunakan dan proses pirolisis (suhu dan alat yang digunakan). Komposisi kompos yang digunakan yaitu $\mathrm{C}$ sebesar 12,30\%, C/N ratio 15-19, $\mathrm{pH} 8,03$ dan kadar air 8,16\% dengan bentuk granul (Agussalim, 2016).

\section{Sifat Fisik Tanah}

Hasil analisis laboratorium sifat fisik tanah menunjukkan pengaruh pemberian kompos dan biochar terhadap penurunan berat volume tanah dengan tesktur tanah klei (clay) dalam Tabel 2 .

Tabel 2. Pengaruh Biochar dan Kompos Terhadap Berat Volume (BV) Tanah

\begin{tabular}{rlllllllllll}
\hline & \multicolumn{10}{c}{ Berat Volume Tanah $\left(\mathrm{g} . \mathrm{cm}^{-3}\right)$} \\
\cline { 2 - 11 } Kompos & \multicolumn{10}{c}{ Biochar } \\
\cline { 2 - 11 } & B0 & B1 & B2 & B3 & B4 \\
K0 & 1,02 & Aa & 1,00 & Aab & 0,79 & Ad & 0,97 & Ab & 0,88 & Ac \\
K1 & 0,94 & Ba & 0,82 & Bb & 0,75 & Ac & 0,83 & Bb & 0,81 & Bb \\
\hline
\end{tabular}

* / Huruf kapital (vertikal) dan huruf kecil (horizontal). Angka yang diikuti huruf yang berbeda pada kolom yang sama menunjukkan perbedaan nyata dengan uji DMRT pada taraf $5 \%$.

Berat volume tanah terendah terdapat pada perlakuan kombinasi kompos 10 ton/ha dan biochar batang jagung 40 ton/ha (K1B2) mencapai $0,75 \mathrm{~g} \cdot \mathrm{cm}^{-3}$ dan berbeda tidak nyata dengan K1B4. Perlakuan K1B2 mampu menurunkan BV sebesar 26,5\% dari BV kontrol (1,02 g.cm-3). Hasil ini sesuai dengan hasil penelitian Barus (2016) yang menunjukkan aplikasi kompos 10 ton dan biochar 10 ton mampu menurunkan berat volume tanah sampai 7,5\%. Pemberian kompos 10 ton/ha dan biochar batang jagung 40 ton/ha (K1B2) merupakan perlakuan terbaik diantara perlakuan lainnya. 


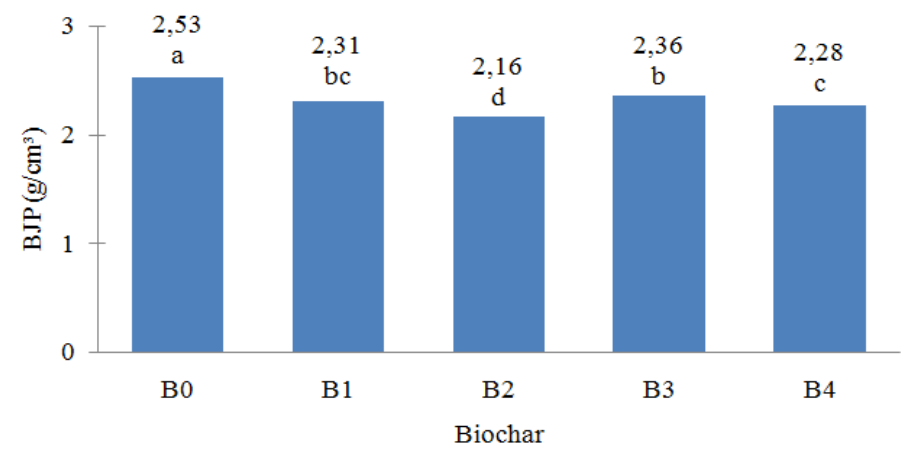

Gambar 2. Pengaruh biochar terhadap berat jenis partikel (g.cm $\left.{ }^{-3}\right)$

Berat jenis partikel (BJP) terendah diperoleh pada pemberian biochar batang jagung 40 ton/ha (B2) sebesar 2,16 g.cm ${ }^{-3}$. BJP tertinggi terdapat pada kontrol (B0) mencapai 2,53 g.cm-3. Penelitian Liescahyani et al (2015) menunjukkan aplikasi biochar mampu menurunkan BJP tanah 5,7\% karena berubahnya komponen penyusun partikel tanah. Penurunan BJP dipengaruhi komponen penyusun partikel tanah.

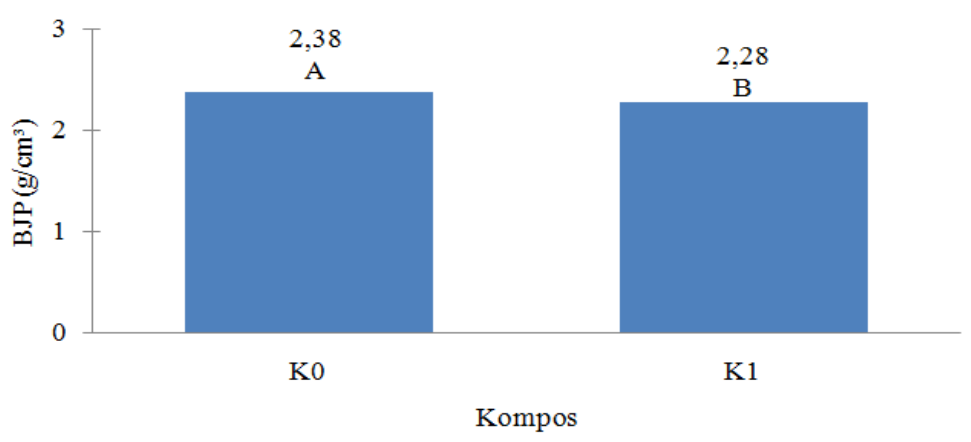

Gambar 3. Pengaruh kompos terhadap berat jenis partikel (g.cm³)

Berdasarkan gambar (3) pemberian kompos 10 ton/ha (K1) mampu menurunkan BJP tanah mencapai 2,28 g.cm-3 berbeda nyata dibandingkan dengan kontrol yang menunjukkan nilai BJP sebesar 2,38 g.cm-3. Ayu (2013) menunjukkan dengan semakin tinggi dosis bahan organik, maka semakin rendah nilai BJP tanah. Pemberian kompos 10 ton/ha menurunkan BJP tanah sebesar $4,2 \%$ dari kontrol.

Tabel 4. Pengaruh Biochar dan Kompos Terhadap Berat Jenis Porositas Tanah

\begin{tabular}{rlllllllllll}
\hline & \multicolumn{10}{c}{ Porositas Tanah (\%) } \\
\cline { 2 - 11 } Kompos & \multicolumn{10}{c}{ Biochar } \\
\cline { 2 - 12 } & B0 & B1 & \multicolumn{1}{c}{ B2 } & B3 & B4 \\
\hline K0 & 59,82 & Bb & 57,41 & Bc & 63,94 & Aa & 60,27 & Bb & 62,71 & Aa \\
K1 & 62,83 & Aa & 64,02 & Aa & 64,74 & Aa & 63,90 & Aa & 63,06 & Aa \\
\hline
\end{tabular}

*/ Huruf kapital (vertikal) dan huruf kecil (horizontal). Angka yang diikuti huruf yang berbeda pada kolom yang sama menunjukkan perbedaan yang nyata menurut uji DMRT pada taraf $5 \%$.

Interaksi kompos dan biochar menunjukkan berbeda nyata terhadap porositas tanah dapat dilihat pada tabel 3. Kombinasi perlakuan terbaik dalam meningkatkan porositas tanah yaitu 
kombinasi kompos 10 ton/ha dan biochar batang jagung 40 ton/ha (K1B2) meningkatkan porositas tanah mencapai $64,74 \%$ berbeda sangat nyata dengan kontrol (K0B0) hanya sebesar $59,82 \%$. Hal ini terjadi karena menurunnya berat volume tanah. Menurut Khoiriyah et al., (2016) penurunan berat volume tanah menyebabkan peningkatan porositas tanah. Pemberian kompos 10 ton/ha dan biochar batang jagung 40 ton/ha meningkatkan porositas tanah.

\section{Distribusi Pori Tanah}

Air tersedia pada tanah dapat dilihat pada tanah dengan melihat distribusi pori tanah menggunakan metode pengukuran $\mathrm{pF}$ tanah. Air tersedia pada tanah selama penelitian dapat dilihat pada Tabel 5.

Tabel 5. Distribusi Pori Tanah $\left(\mathrm{cm}^{3} \cdot \mathrm{cm}^{-3}\right)$

\begin{tabular}{ccccc}
\hline Perlakuan & Pori Aerasi & $\begin{array}{c}\text { Pori Air Mudah } \\
\text { Tersedia } \\
(\mathbf{p F ~ 1 , 8 - 2 , 5 )}\end{array}$ & $\begin{array}{c}\text { Pori Air Agak } \\
\text { Mudah Tersedia } \\
(\mathbf{p F} \mathbf{2 , 5}-\mathbf{4}, \mathbf{2})\end{array}$ & $\begin{array}{c}\text { Pori Air tidak } \\
\text { Tersedia } \\
(\mathbf{p F} \mathbf{4}, \mathbf{2})\end{array}$ \\
\hline K0B0 & 0,11 & 0,14 & 0,14 & 0,14 \\
K0B1 & 0,11 & 0,16 & 0,16 & 0,15 \\
K0B2 & 0,13 & 0,17 & 0,21 & 0,16 \\
K0B3 & 0,14 & 0,16 & 0,24 & 0,15 \\
K0B4 & 0,11 & 0,19 & 0,17 & 0,16 \\
K1B0 & 0,13 & 0,17 & 0,22 & 0,16 \\
K1B1 & 0,11 & 0,19 & 0,14 & 0,15 \\
K1B2 & 0,16 & 0,19 & 0,31 & 0,16 \\
K1B3 & 0,13 & 0,17 & 0,22 & 0,16 \\
K1B4 & 0,13 & 0,17 & 0,25 & 0,17 \\
\hline
\end{tabular}

Pori air agak mudah tersedia pada tanah tertinggi terdapat pada kombinasi kompos 10 ton/ha dan biochar batang jagung sebanyak 40 ton/ha (K1B2) yaitu sebesar $0,31 \mathrm{~cm}^{3} \cdot \mathrm{cm}^{-3}$. Pori air agak mudah tersedia paling rendah terdapat pada pemberian biochar batang jagung 20 ton/ha tanpa kompos (K0B1) yaitu sebesar 18,91\%. Wahjuni et al. (2008) menyatakan distribusi pori pada tanah mempengaruhi pergerakan dan ketersediaan air tanah. Pemberian bahan organik dengan dosis lebih tinggi meningkatkan ketersediaan air dalam tanah.

\section{Berat Basah dan Kering Tanaman}

Berat basah tanaman tertinggi terdapat pada pemberian biochar batang jagung 20 ton/ha (B1) sebesar 422,16 g, sedangkan terendah terdapat pada perlakuan kontrol (B0) hanya menghasilkan berat basah tanaman sebesar 350,11 g. Kurniawan et al. (2016) menyatakan bahwa berat basah tanaman dipengaruhi oleh tinggi tanaman dan luas daun, semakin tinggi tanaman dan luas daun maka berat basah tanaman akan semakin meningkat. Pemberian biochar batang jagung 20 ton/ha tanpa kompos mampu meningkatkan berat basah tanaman. 


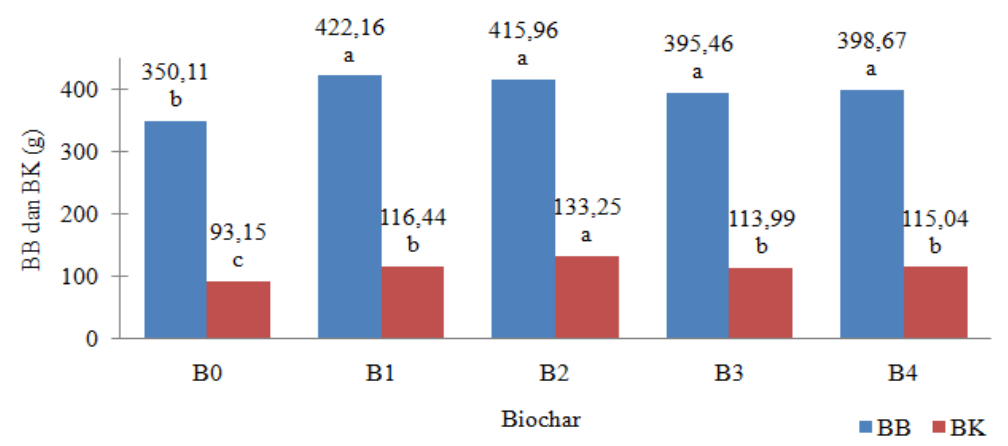

Gambar 4. Pengaruh biochar terhadap berat basah dan berat kering tanaman

Berat kering tanaman tertinggi terdapat pada perlakuan pemberian biochar batang jagung sebesar 40 ton/ha (B2) yaitu sebesar 133,25 g. Berat kering tanaman terendah terdapat pada kontrol (B0) hanya menunjukkan berat kering sebesar 93,15 g. Penelitian Rona et al. I(2015) menunjukkan peningkatan berat kering tanaman setelah aplikasi biochar sekam padi 2,5 ton/ha. Pemberian biochar batang jagung 40 ton/ha tanpa kompos mampu meningkatkan berat kering tanaman.

\section{Kebutuhan Air Tanaman}

Kebutuhan total air tanaman tertinggi terjadi pada kontrol (K0B0) yaitu sebesar 258,64 mm.tanaman ${ }^{-1}$ dan terendah terdapat pada perlakuan kombinasi kompos 10 ton/ha dan biochar jerami padi 40 ton/ha (K1B4) yaitu hanya 169,78 mm.tanaman-1. Penelitian Cornelissen et al. (2013) menunjukkan bahwa biochar dan kompos mampu meningkatkan ketersediaan air untuk tanaman sebesar 17-21\%. Pemberian kompos 10 ton/ha dan biochar jerami padi 40 ton/ha mampu menurunkan kebutuhan air tanaman.

Tabel 8. Pengaruh Biochar dan Kompos terhadap Kebutuhan Total Air Tanaman (ETc)

\begin{tabular}{|c|c|c|c|c|c|c|c|c|c|c|}
\hline \multirow{3}{*}{$\begin{array}{c}\text { Kompos } \\
\text { K0 }\end{array}$} & \multicolumn{9}{|c|}{ Biochar } & \\
\hline & B0 & & B1 & & B2 & & B3 & & B4 & \\
\hline & 258,64 & $\mathrm{Aa}$ & 222,85 & Ac & 195,19 & $\mathrm{Ad}$ & 239,11 & $\mathrm{Ab}$ & 187,11 & Ad \\
\hline K1 & 211,29 & $\mathrm{Ba}$ & 207,08 & $\mathrm{Ba}$ & 173,65 & $\mathrm{Bb}$ & 187,96 & $\mathrm{Bb}$ & 169,78 & $\mathrm{Bc}$ \\
\hline
\end{tabular}

\section{Efisiensi Penggunaan Air Tanaman}

Hasil pengamatan efisiensi penggunaan air tanaman dipengaruhi masing-masing faktor tunggal biochar dan kompos yang berbeda sangat nyata. 


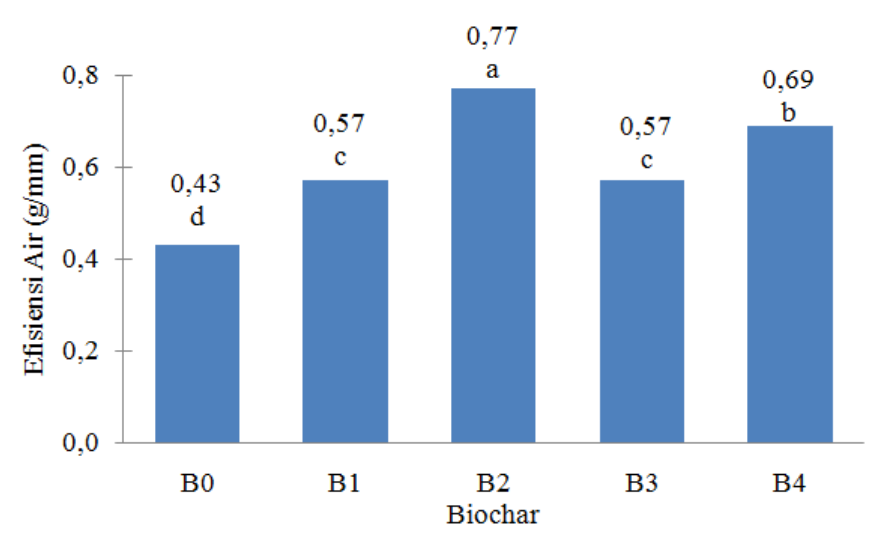

Gambar 7. Pengaruh biochar terhadap Efisiensi Penggunaan Air

Efisiensi air tanaman paling tinggi yaitu sebesar $0,77 \mathrm{~g} / \mathrm{mm}$ diperoleh pada perlakuan pemberian biochar batang jagung sebesar 40 ton/ha (B2). Perlakuan yang memberikan nilai efisiensi penggunaan air terendah yaitu kontrol (B0) hanya mampu mengefisiensi air sebesar $0,43 \mathrm{~g} / \mathrm{mm}$. Hal ini sesuai hasil penelitian Abel et al. (2013), air tersedia pada tanah lebih tersedia dengan aplikasi biochar jagung sehingga mampu meningkatkan efisiensi penggunaan air oleh tanaman. Efsiensi penggunaan air tertinggi oleh pemberian biochar batang jagung 40 ton/ha (B2) terjadi karena semakin besar dosis yang diaplikasikan maka efisiensi penggunaan air tanaman semakin meningkat.

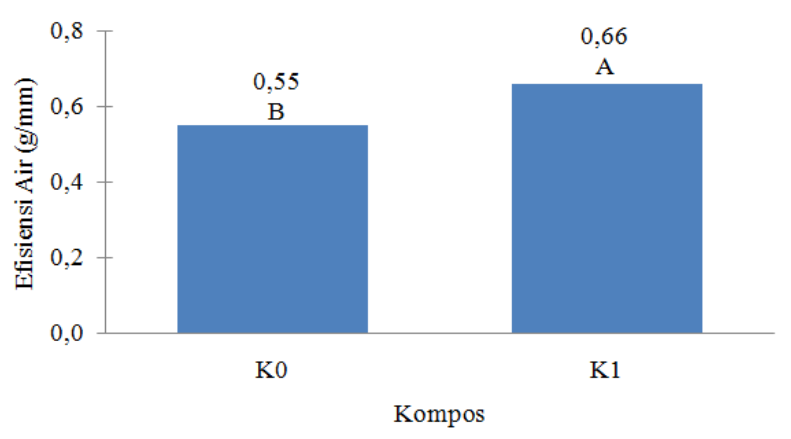

Gambar 8. Pengaruh kompos terhadap efisiensi penggunaan air

Efisiensi penggunaan air tanaman dipengaruhi oleh faktor tunggal kompos. Perlakuan dengan kompos 10 ton/ha (K1) mampu memberikan efisiensi penggunaan air tanaman sebesar 0,66 $\mathrm{g} / \mathrm{mm}$ tanaman dibandingkan dengan kontrol (K0) yang hanya mampu mengefisiensi penggunaan air tanaman sebesar $0,55 \mathrm{~g} / \mathrm{mm}$ tanaman. Hal ini terjadi karena kompos merupakan bahan organik yang mampu meningkatkan kemampuan tanah meretensi air sehingga air lebih tersedia pada tanaman.

\section{KESIMPULAN}

1. Kombinasi kompos 10 ton/ha dan biochar batang jagung 40 ton/ha menurunkan BV $(26,5 \%)$, meningkatkan porositas $(9,2 \%)$ dan menurunkan kebutuhan total air tanaman $(34,4 \%)$ dan meningkatkan air tersedia tanah $(61,9 \%)$. 
2. Pemberian biochar batang jagung 40 ton//ha meningkatkan berat basah tanaman $(20,6 \%)$, berat kering tanaman $(30,1 \%)$.

3. Pemberian biochar jerami 40 ton/ha menghasilkan efisiensi pengguna an air sebesar $51,0 \%$.

4. Perlakuan terbaik terhadap parameter pengamatan jagung manis adalah kombinasi pemberian kompos 10 ton/ha dan biochar batang jagung 40 ton/ha.

\section{SARAN}

Banyak penelitian dengan perlakuan kompos, biochar ataupun kombinasinya menunjukkan hasil yang baik. Diperlukan kajian lebih luas penelitian lapangan untuk pengaruh residu aplikasi terhadap perubahan sifat tanah dan ketersediaan air pada berbagai jenis tanah dan kondisi iklim terhadap respon tanaman pangan.

\section{UCAPAN TERIMA KASIH}

Untuk Hely Setyono yang mempersiapkan data dan peralatan stasiun iklim dan Cacuk Purnomo yang membantu analisis fisika tanah kami sampaikan terimakasih.

\section{DAFTAR PUSTAKA}

Abel, S., A. Peters, S. Trinks, H. Schonsky, M. Facklam and G. Wessolek. 2013. Impact of Biochar and Hydrochar Addition on Water Retention and Water Repellency of Sandy Soil. Geoderma: 183-191.

Agussalim. 2016. Efektifitas Pupuk Organik terhadap Produktivitas Tanaman Kakao di Sulawesi Tenggara. Pengkajian dan Pengembangan Teknologi Pertanian, 19(2): 167-176.

Allen, R. G., L.S. Pereira, D. Raes and M. Smith. 2006. Crop Evapotranspiration: Guidelines for computing crop water requirements. FAO Irrigation and Drainage Paper No. 56. Rome.

Anyia, A.O. dan Herzog, H. 2004. Water-use-efficiency, Leaf Area and Leaf Gas Exchange of Cowpeas Under Mid-Season Drought. Journal of Agronomy, 20: 327-339.

Ayu, S.P. Cinta. 2013. Kapasitas Maksimum Kepadatan Tanah Pada Berbagai Distribusi Ukuran Partikel dan Kadar Bahan Organik Tanah dalam Kondisi Kering Udara dan Kapasitas Lapang. Skripsi. Institut Pertanian Bogor, Bogor.

Barus. 2016. Utilization of Crops Residues as Compost and Biochar for Improving Soil Physical Properties and Upland Rice Productivity. Degraded and Mining Lands Management, 3(4): 631-637.

Cornelissen, G., V. Martinsen,V. Shitumbanuma, V. Alling, G.D. Breedveld, D.W. Rutherford, M. Sparrevik, S.E. Hale, A. Obia and J. Mulder. 2013. Biochar Effect on Maize Yield and Soil Characteristics in Five Conservation Farming Sites in Zambia. Agronomi, 3: 256-274.

Dwiratna, N.P.S., G. Nawawi dan C. Asdak. 2013. Analisis Curah Hujan dan Aplikasinya dalam Penetapan Jadwal dan Pola Tanam Pertanian Lahan Kering di Kabupaten Bandung. Bionatura, 15(1): 29-34.

Hartatik, W., H. Wibowo dan J. Purwani. 2015. Aplikasi Biochar dan Tithoganic dalam Peningkatan Produktivitas Kedelai (Glycine max L.) pada Typic Kanhapludults Di Lampung Timur. Tanah dan Iklim, 39(1): 51-62. 
Heksaputra, D., Y. Apzani, Z. Naimah dan L. Iswari. 2013. Penentuan Pengaruh Iklim terhadap Pertumbuhan Tanaman dengan Naive Bayes. Prosiding Seminar Nasional Aplikasi Teknologi Informasi: 1-6.

Jangpromma, N., Thammasirirak, S., Jaisil P. dan Songsri, P. 2012. Effects of Drought and Recovery from Drought Stress on above Ground, Root Growth and Water Use Efficiency in Sugarcane (Saccharum officinarum L.). Australian Journal of Crop Science 6(8): 1298-1304.

Khoiriyah, A.N., C. Prayogo dan Widianto. 2016. Kajian Residu Biochar Sekam Padi, Kayu dan Tempurung Kelapa terhadap Ketersediaan Air Pada Tanah Lempung Berliat. Tanah dan Sumberdaya Lahan, 3(1): 253-260.

Kurniawan, A., B. Haryono, M. Baskara dan S.Y. Tyasmoro. 2016. Pengaruh Penggunaan Biochar pada Media Tanam terhadap Pertumbuhan Bibit Tanaman Tebu (Saccharum officinarum L.). Produksi Tanaman, 4(2): 153-160.

Liescahyani, I., H. Djatmiko dan N. Sulistyaningsih. 2015. Pengaruh Kombinasi Bahan Baku dan Ukuran Partikel Biochar terhadap Perubahan Sifat Fisika Tanah Pasiran. Berkala Ilmiah Pertanian, 1(1): 1-6.

Maftu'ah, E. dan D. Nursyamsi. 2015. Potensi Berbagai Bahan Organik Rawa Sebagai Sumber Biochar. Prosiding Seminar Nasional Masy Biodiv Indon, 1(4): 776-781.

Mawardiana, Sufardi dan E. Husein. 2013. Pengaruh Residu Biochar Dan Pemupukan NPK Terhadap Sifat Kimia Tanah dan Pertumbuhan Serta Hasil Tanaman Padi Musim Tanam Ketiga. Konservasi Sumber Daya Lahan, 1(1): 16-23.

Munir, M. 1996. Tanah - Tanah Utama Indonesia: Karakteristik, Klasifikasi dan Pemanfaatannya. Jakarta: PT Dunia Pustaka Jaya.

Nurida, N. Laela. 2014. Potensi Pemanfaatan Biochar untuk Rehabilitasi Lahan Kering di Indonesia. Sumberdaya Lahan, 57-68.

Pathak, P., R. Sudi, S.P. Wani and K.L. Sahrawat. 2013. Hydrological Behavior of Alfisols and Vertisols in the Semi-Arid Zone: Implications for Soil and Water Management. Agricultural Water Management, 118: 12-21.

Rona, Y., Widowati dan Sutoyo. 2015. Penggunaan Kompos dan Biochar untuk Pembibitan, Pertumbuhan dan Hasil Cabai Rawit (Capsicum frutenscen L.). Universitas Tribuwana Thunggadewi Malang.

Singh, A., Anggarwal, N., Aulakh, G.S. dan Hundal, R.K. 2012. Ways to Maximize The Water Use Efficiency in Field. Agricultural Sciences, 2(4): 108-129.

Suriadikarta, D.A., T. Prihatini, D. Setyorini dan W. Hartatiek. 2002. Teknologi Pengelolaan Lahan Kering Menuju Pertanian Produktif dan Ramah Lingkungan. Puslitbang Tanah.

Wahjunie, E.D., D. Haridjaja, H. Soedodo dan Sudarsono. 2008. Pergerakan Air Tanah dengan Karakteristik Pori Berbeda dan Pengaruhnya pada Ketersediaan Air Bagi Tanaman. Tanah dan Iklim, 28: 15-26.

Widowati dan Sutoyo. 2013. Kombinasi Jenis Biochar dan Perimbangan Pupuk NPK Terhadap Pertumbuhan dan Hasil Jagung Pada Tanah Terdegradasi. Prosiding, 1-10.

Wijanarko, A., Sudaryono dan Sutarno. 2007. Karakteristik Sifat Kimia dan Fisika Tanah Alfisol di Jawa Timur dan Jawa Tengah. Iptek Tanaman Pangan, 2(2): 214-216. 